No 4077

Studia nad Autorytaryzmem i Totalitaryzmem 43, nr 3

Wrocław 2021

https://doi.org/10.19195/2300-7249.43.3.18

\author{
MACIEJ GAJOS \\ ORCID: 0000-0002-9183-0709 \\ Uniwersytet Wrocławski \\ maciej.gajos@uwr.edu.pl
}

\title{
Wprowadzenie dyktatury wojskowej w wyniku zamachu stanu \\ a kwestia międzynarodowego uznania rządu na przykładzie przewrotu wojskowego w Mjanmie z 1 lutego 2021 roku
}

Słowa kluczowe: Mjanma, junta, Tatmadaw, zamach stanu, uznanie rządu.

\section{THE ESTABLISHMENT OF MILITARY DICTATORSHIP THROUGH A COUP D'ÉTAT AND THE QUESTION OF INTERNATIONAL RECOGNITION OF A GOVERNMENT IN THE CONTEXT OF THE 1 FEBRUARY 2021 COUP IN MYANMAR}

\begin{abstract}
The article reflects on the question of recognizing a government in international law in relation to the coup that took place in Myanmar on 1 February 2021. First, the author defines the recognition of a government, emphasizing that the institution of recognition applies exclusively to unconstitutional changes of governments. The circumstances of the coup in Myanmar are recounted, exhibiting that the authoritarian regime of the junta has been established in a manifest violation of provisions established in the Constitution adopted in 2008. Second, the competing criteria for recognition of a government in international law are discussed with reference to Tobar (favoring legitimacy) and Estrada doctrines (according to which effectiveness shall prevail). The author presents the evolution of opinions in scholarship and in the practice of states that occurred over the course of decades and led to the dominance of the latter concept. It is demonstrated that upon the application of the criterium of effectiveness with regard to the junta in Myanmar, it should be recognized as a body entitled to represent the state. Finally, acknowledging the tendency that originated in the 1990s to take into account the democratic norm as an alternative basis for recognition of a government or its denial,
\end{abstract}


the author claims that in the lack of coherent and uniform state practice in that field, such a norm cannot create a normative obligation as a norm of customary international law, and therefore does not justify nonrecognition of junta.

Keywords: Myanmar, junta, Tatmadaw, coup, recognition of government.

Siły zbrojne w Mjanmie (Tatmadaw) 1 lutego 2021 roku ogłosiły wprowadzenie na rok stanu wyjątkowego i powołanie Państwowej Rady Administracyjnej, na której czele stanął głównodowodzący armii gen. Min Aung Hlaing ${ }^{1}$. Państwo ogarnęła fala protestów: demonstracje obywateli spotykają się z nieproporcjonalną, nader brutalną reakcją sił bezpieczeństwa: do 1 kwietnia co najmniej 510 pokojowych demonstrantów zostało zabitych przez funkcjonariuszy, którzy posługują się między innymi bronią ciężką, karabinami maszynowymi i granatami, a „nocne naloty, masowe aresztowania i zabójstwa stały się codziennością w całym kraju"2. W połowie lutego na forum Rady Praw Człowieka ONZ przyjęto rezolucję, w której stanowczo potępiono obalenie demokratycznie wybranego rządu i wezwano do uwolnienia arbitralnie przetrzymywanych więźniów ${ }^{3}$. Temat Mjanmy powrócił na forum Rady miesiąc później, 11 marca, gdy zajmowała się ona raportem T. Andrewsa, specjalnego sprawozdawcy ONZ ds. praw człowieka w Mjanmie. Andrews oświadczył, że Mjanma „kontrolowana jest przez morderczy i nielegalny reżim", i wezwał państwa do nieuznawania junty za legalny rząd ${ }^{4}$. Jednocześnie jednak, jak zauważa L.D. Johnson, nikt z obecnych nie protestował, gdy w trakcie posiedzeń Rady Praw Człowieka oficjalnie w imieniu Mjanmy głos zabierał przedstawiciel junty właśnie, który bronił decyzji o ogłoszeniu stanu

${ }^{1}$ BBC News, Myanmar coup: Aung San Suu Kyi detained as military seizes control, 1.02.2021, https://www.bbc.com/news/world-asia-55882489 (dostęp: 13.04.2021).

${ }^{2}$ UN Human Rights South-East Asia Regional Office, UN Human Rights Office urges suspension of returns to Myanmar, 1.04.2021, https://bangkok.ohchr.org/myanmar-returns/ (dostęp: 14.04.2021).

${ }^{3}$ United Nations Human Rights Council, Human Rights Council calls for release of all arbitrarily detained persons in Myanmar, and lifting of state of emergency, 12.02.2021, https://www.ohc hr.org/EN/HRBodies/HRC/Pages/NewsDetail.aspx?NewsID=26748\&LangID=E (dostęp: 15.04.2021). W ciągu dwu miesięcy od zamachu stanu aresztowano ponad 2600 osób, w tym: członków NLD, parlamentarzystów, urzędników państwowej komisji wyborczej, dziennikarzy czy też działaczy społeczeństwa obywatelskiego. Jedną z pierwszych aresztowanych osób była Aun San Suu Kyi, laureatka Pokojowej Nagrody Nobla, dotychczas zajmująca stanowisko radcy państwa, zatrzymana pod zarzutami, które mogą wydawać się błahe czy groteskowe: mianowicie oskarża się ją o posiadanie nielegalnych walkie-talkie (zob. R. Gladstone, Illegal Walkie-Talkies and Other 'Crimes' in Authoritarian Societies, „The New York Times” 8.02.2021, https://www.nytimes.com/2021/02/08/ world/asia/authoritarians.html?searchResultPosition=87 (dostęp: 13.04.2021)).

${ }^{4}$ UN Geneva, After a Decade of Civilians Bearing the Brunt of the Conflict in Syria, it is Time to Put Them First and Support an Immediate Nation-wide Ceasefire, Commission of Inquiry on Syria Tells Human Rights Council, 11.03.2021, https://www.ungeneva.org/en/news-media/ meeting-summary/2021/03/afternoon-after-decade-civilians-bearing-brunt-conflict-syria-it (dostęp: 13.04.2021). 
wyjątkowego i podkreślał „powściągliwość” nowej władzy w reakcjach na protesty $^{5}$. Można było także w tym czasie zaobserwować początkowe etapy kształtowania się rządu na uchodźstwie: tak zwanego Komitetu Reprezentującego Pyidaungsu Hluttaw (CRPH), złożonego głównie z członków NLD wybranych do parlamentu w listopadzie, z ukrywającym się przed służbami bezpieczeństwa Mahn Win Khang Thanem, pełniącym obowiązki wiceprezydenta, na czele, który przystąpił do podejmowania dyplomatycznych zabiegów o uznanie na arenie międzynarodowej ${ }^{6}$.

Nasuwa się w tym kontekście pytanie, w jaki sposób państwa trzecie mogą czy też powinny $\mathrm{w}$ zaistniałych okolicznościach określić swoją pozycję wobec junty sprawującej obecnie autorytarną władzę w państwie. Celem niniejszego artykułu jest próba zbadania możliwości zastosowania do stanu faktycznego zaistniałego w Mjanmie norm dotyczących instytucji uznania rządu w prawie międzynarodowym publicznym.

\section{Kiedy w prawie międzynarodowym ma miejsce uznanie rządu a przypadek przewrotu wojskowego w Mjanmie}

Należy zaznaczyć słowem wstępu, że uznanie rządu nie jest definiowane jednoznacznie w doktrynie: S. Talmon pisze o dwóch przypisywanych mu znaczeniach, pozornie konkurencyjnych, jednak zazwyczaj występujących jednocześnie i wzajemnie się wzmacniających: uznanie, z jednej strony — sygnalizowanie woli (lub jej braku) nawiązania lub utrzymywania oficjalnych relacji z danym rządem ${ }^{7}$, z drugiej zaś - wyrażenie opinii na temat prawnego statusu nowo powstałego rzą$\mathrm{du}^{8}$. Trzeba wskazać, że jest to jednostronny akt państwa, w formie bezpośredniej lub dorozumianej ${ }^{9}$, wywołujący doniosły skutek w prawie międzynarodowym: „państwo, które uznało pewne roszczenie lub istniejący stan faktyczny, nie może kwestionować jego legalności w przyszłości"10. Uznanie rządu wyraźnie różni się od uznania państwa; jak pisze J.A. Frowein, zmiany rządów w poszczególnych państwach co do zasady przynależą do domeny prawa krajowego i nie są przedmiotem zainteresowania prawa międzynarodowego - o ile zmiana dokonuje się

5 L.D. Johnson, What's wrong with this picture? The UN Human Rights Council hears the military Junta as the legitimate government of Myanmar, EJIL: Talk! 31.03.2021, https://www.ejil talk.org/whats-wrong-with-this-picture-the-un-human-rights-council-hears-the-military-junta-asthe-legitimate-government-of-myanmar/ (dostęp: 14.04.2021).

6 A. Mendelson, Vying for legitimacy as Myanmar's recognised government, who are the CRPH?, „Globe” 12.03.2021, https://southeastasiaglobe.com/crph-myanmar/ (dostęp: 18.04.2021).

7 S. Talmon, Recognition of Governments in International Law: With Particular Reference to Governments in Exile, Oxford 2001, s. 23.

8 Ibidem, s. 29-30.

9 V. Rodriguez-Cedeno, Sixth report on unilateral acts of States, A/CN.4/519, 2003, pkt 25.

10 Ibidem, pkt 96. 
w przewidzianych konstytucyjnie ramach ${ }^{11}$. E. Dynia wskazuje, że uznanie rządu znajdzie zastosowanie tylko w wypadku rządu ,powstałego w drodze pozakonstytucyjnej: w wyniku zamachu stanu, rewolucji czy interwencji wojskowej ze strony państw trzecich" ${ }^{2}$. Badając stan faktyczny w Mjanmie, należy najpierw ustalić więc, czy mamy do czynienia z sytuacją, w której do zmiany władzy dochodzi z pogwałceniem konstytucji.

Do puczu doszło bezpośrednio przed rozpoczęciem pierwszej sesji nowego parlamentu, powołanego w wyborach 8 listopada 2020 roku. Zdecydowane zwycięstwo odniosła w nich Narodowa Liga na rzecz Demokracji (396 na 476 mandatów), podczas gdy wspierane przez wojsko Stowarzyszenie Solidarności i Rozwoju zdobyło zaledwie 33 miejsca $^{13}$. Protesty wyborcze zgłaszane przez przegranych zostały rozpatrzone przez komisję wyborczą, która nie stwierdziła żadnych istotnych naruszen ${ }^{14}$. Wynik wyborów, trudny do zaakceptowania dla sił zbrojnych, zachwiał dotychczasowym status quo w państwie: Mjanma, po ponad 50 latach rządów autorytarnych $(1958-1960,1962-2011) \mathrm{w}$ drugiej dekadzie XXI wieku wkroczyła na ścieżkę transformacji ustrojowej, jednak do ugruntowania się demokracji nigdy nie doszło. Powstał ustrój określany jako hybrydowy (,zdyscyplinowana demokracja”) ${ }^{15}$, w którym na mocy przyjętej w 2008 roku konstytucji przewidziana jest szczególna pozycja Tatmadaw: armia zachowuje daleko idącą autonomię, głównodowodzący sił zbrojnych nominuje ministrów i wiceministrów obrony, spraw wewnętrznych i spraw granic ${ }^{16}$, ponadto armii przypada $25 \%$ miejsc w obu izbach parlamentu ${ }^{17}$. Generałowie tym samym nigdy nie zgodzili się na poddanie ich ograniczeniom, które pozwoliłyby Mjanmie stać się prawdziwą demokracją ${ }^{18}$; dopuścili jedynie pewne jej koncesjonowane przejawy, jak choćby wybory, które wszakże trudno byłoby określić jako powszechne i równe, ze względu na przykład na wykluczenie $\mathrm{z}$ udziału w nich mniejszości etnicznej Rohindżów ${ }^{19}$. Jak wskazuje M. Lubina w swojej ocenie

11 J.A. Frowein, Recognition, Max Planck Encyclopedia of Public International Law, https:// opil.ouplaw.com/view/10.1093/law:epil/9780199231690/law-9780199231690-e1086?rskey=wHv Nc2\&result=1\&prd=OPIL, pkt 14 (dostęp: 15.04.2021).

12 E. Dynia, Uznanie rzadu w prawie międzynarodowym, Lublin 1997, s. 27.

13 T.H. Andrews, Report of the Special Rapporteur on the situation of human rights in Myanmar, A/HRC/46/56, 4.03.2021, s. 2.

14 Ibidem, s. 3.

15 M. Lubina, Krwawy księżyc, „Polityka” 2021, nr 16 (3308), s. 43.

${ }^{16}$ K. Stokke, S. Myint Aung, Transition to Democracy or Hybrid Regime? The Dynamics and Outcomes of Democratization in Myanmar, „The European Journal of Development Research” 32, 2019, nr 1, s. 285.

17 A. Barker, Myanmar election: Why can't Aung San Suu Kyi be president and why is the country in leadership limbo?, „ABC News” 10.11.2015, https://www.abc.net.au/news/2015-11-10/myan mar-election-explained/6928542?nw=0 (dostęp: 18.04.2021).

18 A. Selth, Interpreting Myanmar: A Decade of Analysis, Canberra 2020, s. 392.

19 Human Rights Watch, Myanmar: Election Fundamentally Flawed, 5.10.2020, https://www. hrw.org/news/2020/10/05/myanmar-election-fundamentally-flawed (dostęp: 15.04.2021) 
transformacji w Mjanmie: ,politycznie niewiele się zmieniło”, widoczna jest za to różnica w „dekoracjach, czyli marketingu politycznym" 20 — dekoracjach, które teraz zdecydowano się zmienić. Wprowadzając stan wyjątkowy, Tatmadaw powołuje się na podstawę konstytucyjną, to jest art. 417 rozdziału XI dotyczącego możliwości wprowadzenia stanu wyjątkowego, wiążącego się z zawieszeniem praw obywatelskich i przekazaniem pełni władzy ustawodawczej, wykonawczej i sądowniczej na ręce szefa sił zbrojnych. Jak jednak wskazuje Andrews, nie zaistniała żadna z przesłanek, która pozwalałaby na skorzystanie z tej prerogatywy: jakkolwiek nieprecyzyjnie określono w konstytucji sytuacje „grożące rozpadem Związku”, ,rozbiciem narodowej solidarności” czy „powodujące utratę suwerenności", domniemane nieprawidłowości wyborcze nie będą wypełniać ich znamion $^{21}$. Co więcej, aby stan wyjątkowy został wprowadzony legalnie, wymaga on ogłoszenia przez prezydenta po konsultacji z Narodową Radą Bezpieczeństwa i Obrony - wymogów tych ewidentnie nie dopełniono ${ }^{22}$. Tym samym należy stwierdzić, że objęcie władzy nastąpiło w pogwałceniu konstytucji Mjanmy.

\section{Kryteria uznania rządu i ich adekwatność wobec zamachu stanu w Mjanmie}

W reakcjach przedstawicieli społeczności międzynarodowej na kryzys w Mjanmie wyraźnie brakuje spójności, co może zapowiadać, że również w odniesieniu do samego uznania junty wystąpią rozbieżności, a na pierwszy plan wysuną się czynniki polityczne zamiast prawnych. Stany Zjednoczone, Wielka Brytania i Unia Europejska potępiły przewrót wojskowy i wydały decyzje o nałożeniu sankcji: w wypadku UE środki objęły zakaz wjazdu i zamrożenie aktywów 11 osób odpowiedzialnych za zamach stanu i późniejsze represje wobec pokojowych demonstrantów ${ }^{23}$, Waszyngton i Londyn zdecydowały też o zastosowaniu sankcji ekonomicznych względem konglomeratów będących finansowym zapleczem armii ${ }^{24}$. Tymczasem Rada Bezpieczeństwa (RB) ONZ zdołała zaledwie

20 M. Lubina, Birma: zdyscyplinowana demokracja, ,Miesięcznik Znak” 10.2015, https://www. miesiecznik.znak.com.pl/birma-zdyscyplinowana-demokracja/ (dostęp: 14.04.2021).

21 T.H. Andrews, op. cit., s. 3.

22 Ibidem.

23 Council of the EU, Myanmar/Burma: EU sanctions 11 people over the recent military coup and ensuing repression, 22.03.2021, https://www.consilium.europa.eu/en/press/press-releases/ 2021/03/22/myanmar-burma-eu-sanctions-11-people-over-the-recent-military-coup-and-ensuing-re pression/ (dostęp: 18.04.2021).

24 Sankcjami obciążono spółki takie jak Myanmar Economic Corporation i Myanmar Economic Holdings Ltd., jednak trudno oczekiwać po tych środkach znaczącej skuteczności, zważywszy, że najważniejszymi partnerami handlowymi Mjanmy pozostają Chińska Republika Ludowa oraz Tajlandia. Zob. T. McDonald, Myanmar coup: Could sanctions on the military ever work?, BBC News 9.04.2021, https://www.bbc.com/news/business-56248559 (dostęp: 18.04.2021). 
uzgodnić tekst oświadczenia prasowego, w którym wyraża zaniepokojenie sytuacją w Mjanmie i wzywa do uwolnienia przetrzymywanych osób, jednak zabrakło w nim słów wyraźnego potępienia przewrotu; rząd ChRL blokuje surowszą krytykę, konsekwentnie zajmując stanowisko, że jest to wewnętrzna sprawa Mjanmy ${ }^{25}$. Jakkolwiek w uznaniu rządu znaczną rolę odgrywa pierwiastek polityczny ${ }^{26}$, należy jednak dobitnie podkreślić, że normy prawa międzynarodowego publicznego wyznaczają państwom pewną dozwoloną ścieżkę postępowania, a ich dyskrecjonalność w tym zakresie ograniczają przede wszystkim elementarne zasady prawa międzynarodowego, na czele $\mathrm{z}$ zasadą zakazu ingerencji w wewnętrzne sprawy innych państw, która znajduje wyraz między innymi w art. 2 ust. 7 Karty Narodów Zjednoczonych ${ }^{27}$, a także w rezolucji Zgromadzenia Ogólnego ONZ nr 2625 $(X X V)$ z 1970 roku - Zasady prawa międzynarodowego ${ }^{28}$. W pewnych sytuacjach akt uznania rządu może być przesłanką powstania odpowiedzialności międzynarodowej, co dobitnie ilustruje powszechnie uznawany w doktrynie zakaz uznania przedwczesnego: będziemy mieli z nim do czynienia, gdy przy jednoczesnym działaniu dwóch konkurencyjnych rządów rząd rewolucyjny zostaje uznany, zanim obejmie władzę nad znaczną częścią terytorium, a jego zwycięstwo będzie przesądzone (co łączy się bezpośrednio z zasadą efektywności, o której więcej dalej $)^{29}$. Uznanie wówczas będzie stanowiło niedozwoloną ingerencję, a państwo dokonujące uznania narazi się na zarzut naruszenia prawa międzynarodowego ${ }^{30}$.

Uznanie rządu musi być oparte na pewnych konkretnych przesłankach. W pracach H. Lauterpachta można odnaleźć rozróżnienie między dwoma zasadniczymi kryteriami uznania rządu: legalnością oraz efektywnością ${ }^{31}$. W pierwszej połowie XX wieku krótko popularnością cieszyła się doktryna Tobara, przyznająca pry-

25 S.M. Brooks, D. Stothard, China's Myanmar Mess, „The Diplomat” 16.03.2021, https:// thediplomat.com/2021/03/chinas-myanmar-mess/ (dostęp: 17.04.2021).

${ }^{26}$ Nie tylko chodzi tu o czynniki polityczne wpływające na decyzję państwa o uznaniu; w pewnych wypadkach konieczne jest badanie, czy mamy do czynienia z uznaniem rządu jako aktem jednostronnym państwa tworzącym skutki prawne, czy może z czysto polityczną wypowiedzią, która stanowi formę okazania wsparcia danemu rządowi — tak R. Janik, analizując deklaracje rządów państw europejskich w odniesieniu do rządu J. Guaidó w Wenezueli, zaliczył je właśnie do tej drugiej kategorii (zob. R. Janik, European Recognition Practice on Venezuela: The Devil in the Details, „OpinioJuris” 8.02.2019, http://opiniojuris.org/2019/02/08/european-recognition-practice-onvenezuela-the-devil-in-the-details/ (dostęp: 16.04.2021)).

27 Karta Narodów Zjednoczonych, Dz.U. z 1947 r. Nr 23, poz. 90.

28 UN General Assembly, Declaration on Principles of International Law concerning Friendly Relations and Cooperation among States in accordance with the Charter of the United Nations, 24.10.1970, A/RES/2625(XXV), https://digitallibrary.un.org/record/202170 (dostęp: 15.04.2021).

29 W. Czapliński, A. Wyrozumska, Prawo międzynarodowe publiczne. Zagadnienia systemowe, Warszawa 2014, s. 395.

30 Zob. S. Talmon, Recognition of the Libyan National Transitional Council, „ASIL Insights” 15, 2011, $\mathrm{nr}$ 16, https://www.asil.org/insights/volume/15/issue/16/recognition-libyan-national-trans itional-council (dostęp: 17.04.2021).

31 Zob. H. Lauterpacht, Recognition of Governments: I, „Columbia Law Review” 45, 1945 , nr 6, s. 825-830. 
mat przesłance legalności. Koncepcja przedstawiona przez byłego ministra spraw zagranicznych Ekwadoru na Konferencji Ameryki Środkowej w Waszyngtonie w 1907 roku była odpowiedzią na realia polityczne Ameryki Łacińskiej u progu poprzedniego stulecia, gdzie nieustanne rewolucje i wojny domowe stały na drodze rozwoju. Postulowana odmowa uznawania rządów powstających w drodze pozakonstytucyjnej służyć miała ograniczeniu rozpowszechnionej praktyki zamachów stanu, jednak prędko ujawniła się jej nieskuteczność ${ }^{32}$. W opozycji ukształtowała się doktryna Estrady, ciesząca się znacznie większą aprobatą: koncepcja autorstwa meksykańskiego szefa dyplomacji, który w 1930 roku poinstruował podlegających mu dyplomatów, że od tej pory Meksyk nie będzie zabierał głosu w kwestii uznania rządów powstałych wskutek zamachu stanu lub rewolucji, a procesy wewnętrzne zachodzące w poszczególnych państwach nie będą podlegały ocenie ${ }^{33}$. Według doktryny Estrady przeważać ma kryterium efektywności: jeżeli w państwie $\mathrm{X}$ funkcjonuje faktycznie rząd, nie należy odmawiać mu uznania $^{34}$. W trafny sposób istotę efektywności oddaje M. Weller: „ktokolwiek zdoła przejąć rzeczywistą władzę w państwie, będzie traktowany jako uprawniony do wypowiadania się w jego imieniu na poziomie międzynarodowym"35. Zdaniem Lauterpachta to właśnie efektywność powinna odgrywać rozstrzygającą rolę: podkreśla on, że „rząd efektywnie ustanowiony na terytorium kraju [...] bez względu na jego rewolucyjne pochodzenie, musi być traktowany jako reprezentujący dane państwo i jako taki uprawniony [...] do uznania"36. Zaznacza przy tym, że prawo międzynarodowe nie może sobie pozwolić na ignorowanie faktów ${ }^{37}$. Wskazuje, że kryterium legalności „,należy do przeszłości”; dopatruje się w nim reliktu epoki kongresu wiedeńskiego - prawo międzynarodowe nie interesuje się tym, czy dany rząd powstał w drodze rewolucji, jego funkcją pozostaje zapewnienie pewnego stopnia ciągłości ${ }^{38}$. Odnosząc zatem kryterium efektywności do sytuacji w Mjanmie, należałoby stwierdzić, że stanowi ono wyraźne wskazanie do uznania za rząd w państwie junty właśnie, która sprawuje w tym czasie zupełną kontrolę nad całością aparatu państwa. CRPH zaś, według stanu na 1 kwietnia 2021 roku,

32 C.L. Stansifer, Application of the Tobar Doctrine to Central America, „The Americas” 23, 1967 , nr 3, s. 251-255.

33 P.C. Jessup, The Estrada Doctrine, ,The American Journal of International Law” 25, 1931, nr 4, s. 719-720.

34 Prymat efektywności został potwierdzony w istotnym arbitrażowym rozstrzygnięciu w sprawie Tinoco, w którym sędzia W. Taft stwierdził, że prawo międzynarodowe nie pozwala na odmowę uznania rządu sprawującego de facto władzę z tego tylko powodu, że do jego ustanowienia doszło w sprzeczności z krajową konstytucją (zob. Aguila-Amory and Royal Bank of Canada claims (Great Britain v. Costa Rica), 18.10.1923, Reports of International Arbitral Awards, t. 1, s. 381).

35 M. Weller, Myanmar: Testing the Democratic Norm in International Law, EJIL: Talk! 30.03. 2021, https://www.ejiltalk.org/myanmar-testing-the-democratic-norm-in-international-law/ (dostęp: 17.04.2021).

${ }^{36}$ H. Lauterpacht, op. cit., s. 819.

37 Ibidem.

38 Ibidem, s. 830-832. 
kryterium efektywności z pewnością nie będzie spełniał: w chwili pisania artykułu znajduje się on wciąż na bardzo wczesnym etapie formacji, a liczba jego członków jest nader ograniczona, nie sprawuje on żadnej formy realnej władzy na terytorium państwa ani jakiejkolwiek jego części ${ }^{39}$. Uznanie go za legalny rząd byłoby wielce wątpliwe z punktu widzenia zakazu przedwczesnego uznania.

W praktyce państwa posługują się jeszcze pewnymi dodatkowymi kryteriami, przy czym pozostają one wyraźnie podporządkowane efektywności: można tu wskazać przykładowo wymóg zgody lub milczącego przyzwolenia ludności danego państwa ${ }^{40}$. Lauterpacht pisze o teście wtórnej legitymizacji (rząd, który dochodzi do władzy w drodze do przewrotu, zyskuje mocny mandat społeczny) i wskazuje na wiele wątpliwości ograniczających jego przydatność: choćby skłonności reżimów rewolucyjnych do utrudniania społeczeństwu swobodnego wyrażania opinii, kwestia właściwej procedury, w jakiej taka zgoda miałaby zostać wyrażona, a także związków tego kryterium z wymogiem efektywności (despotyczne rządy mogą pełnić swoje funkcje w sposób efektywny bez poparcia rządzonych $)^{41}$. Drugie dodatkowe kryterium stanowi deklarowanie przez nowo powstały rząd zamiaru wywiązywania się ze zobowiązań międzynarodowych: Lauterpacht również odnosi się do niego krytycznie, łącząc go z ryzykiem transakcyjnego podejścia do uznania (uznanie $\mathrm{w}$ zamian za pewne koncesje i obietnice), a także wskazując, że jest ono zbędne w takim zakresie, w jakim odnosi się do zobowiązań poprzedniego rządu - nowa władza automatycznie będzie nimi związana ${ }^{42}$. Możemy odnotować pewne przypadki wykorzystania tych dwóch kryteriów w praktyce ${ }^{43}$, są one również przedmiotem analiz w literaturze, jednak należy zgodzić się z J.A. Froweinem, który stwierdza, że o ile nie wpływają one bezpośrednio na efektywność rządu, jest ,wątpliwe, czy mogą one zostać wykorzystane do odmowy uznania" 44 . Tym samym wciąż nieuchronnie powracamy do prymatu efektywności: na przykład okoliczność protestów w Mjanmie jest tutaj nieistotna tak długo, jak nie osłabia ona kontroli sprawowanej w państwie przez juntę — można jednak przypuszczać, że ocena sytuacji nie byłaby tak oczywista, gdyby protesty osiągnęły taką skalę, że państwo pogrążyłoby się w wojnie domowej, co jednak w tej chwili pozostaje tylko jednym z możliwych scenariuszy ${ }^{45}$.

39 A. Mendelson, op. cit.

40 J.A. Frowein, op. cit., pkt 16.

41 H. Lauterpacht, op. cit., s. 861-864.

42 Ibidem, s. 837-838.

43 Przykładowo: odmowa uznania przez Stany Zjednoczone Sowieckiej Rosji po rewolucji z 1917 roku uzasadniona brakiem po stronie Sowietów woli wywiązania się z pewnych zobowiązań międzynarodowych zaciągniętych w okresie caratu; uznanie przez Wielką Brytanię rządu greckiego, który objął władzę w 1922 roku po uzyskaniu przez niego mandatu w plebiscycie dwa lata później. Zob. ibidem, s. 836-837, 849.

44 J.A. Frowein, op. cit., pkt 16.

45 Zob. L. Myers, Myanmar Is on the Precipice of Civil War, „Foreign Policy” 8.04.2021, https://foreignpolicy.com/2021/04/08/myanmar-military-coup-ethnic-armed-organizations-civilwar/ (dostęp: 27.04.2021). 


\section{Naruszenie normy demokratycznej jako potencjalna przesłanka odmowy uznania}

Przez pewien czas mogło się wydawać, że spór między legalnością a efektywnością został definitywnie rozstrzygnięty na korzyść tego drugiego kryterium - doktryna wyraźnie straciła zainteresowanie tą problematyką w drugiej połowie $\mathrm{XX}$ wieku ${ }^{46}$. Tymczasem w ciągu ostatniego ćwierćwiecza dał się zaobserwować trend do oceniania przez społeczność międzynarodową demokratycznej legitymacji nowo powstałych rządów: o kształtującym się prawie do demokratycznych rządów pisał T.M. Franck na początku lat dziewięćdziesiątych, powołując się na przypadek Haiti ${ }^{47}$. W 1991 roku, kiedy na wyspie doszło do przewrotu wojskowego, Zgromadzenie Ogólne (ZO) ONZ przyjęło jednogłośnie rezolucję, określaną przez Francka jako przełomową, w której nie tylko surowo potępiono „nielegalną próbę zastąpienia konstytucyjnego prezydenta Haiti”, ale też wezwano do natychmiastowego przywrócenia legalnego rządu prezydenta J.-B. Aristide'a, a także przestrzegania konstytucji i poszanowania praw człowieka ${ }^{48}$ - Franck dopatruje się w tej sytuacji dowodu na stopniowe kształtowanie się normy międzynarodowej, zgodnie z którą tylko demokracja legitymuje rządy ${ }^{49}$. Oceniając ewolucję podejścia do demokracji w prawie międzynarodowym, niewątpliwie można odnotować pewien postęp, związany zwłaszcza ze wzmacnianiem normy demokratycznej przez rozmaite inicjatywy podejmowane na poziomie organizacji międzynarodowych ${ }^{50}$. Weller próbuje dowieść bogatej praktyki w tym zakresie, wskazując, że norma demokratyczna została zastosowana odnośnie do kryzysów między innymi w Burundi, Sierra Leone, Lesotho czy na Madagaskarze, a także w samej Mjanmie, wobec której ZO ONZ wydało w grudniu 1992 roku rezolucję zdecydowanie zrywającą z podejściem zakładającym nieingerowanie w wewnętrzne sprawy innych państw, wzywającą bowiem do przywrócenia demokracji

46 Dobrze trend ten oddaje treść pisma skierowanego przez lorda tajnej pieczęci, sir I. Glamoura, do Izby Gmin z 25 sierpnia 1980 roku, w którym oświadcza on, że po zbadaniu brytyjskiej polityki i praktyki w tym zakresie, a także po porównaniu jej z praktyką partnerów i sojuszników, zadecydowano o zaniechaniu formalnego uznawania rządów (zob. S. Talmon, Recognition of Governments: An Analysis of the New British Policy and Practice, „British Yearbook of International Law" 63, 1992, nr 1, s. 231-297).

47 T.M. Franck, The Emerging Right to Democratic Governance, „The American Journal of International Law" 86, 1992, nr 1, s. 46-91.

48 UN General Assembly, The situation of democracy and human rights in Haiti, 11.10.1991, A/RES/46/7, https://documents-dds-ny.un.org/doc/RESOLUTION/GEN/NR0/580/95/IMG/NR058 095.pdf?OpenElement (dostęp: 16.04.2021).

49 T.M. Franck, op. cit., s. 47. Franck zaznacza zarazem wyraźnie, że jest to dopiero norma in statu nascendi: wciąż nieugruntowana, raczej zapowiedź normy, która dopiero krystalizuje się w prawie międzynarodowym publicznym (ibidem, s. 50).

50 Na przykład prace UNEAD, czyli wydziału Departamentu Spraw Politycznych ONZ zajmującego się pomocą w organizacji wyborów. Zob. S. Marks, What has Become of the Emerging Right to Democratic Governance?, „The European Journal of International Law” 22, 2011, nr 2, s. 511. 
i pełnego poszanowania wyniku wyborów z 1990 roku, a także do bezwarunkowego uwolnienia Aung San Suu Kyi (wrażenie déjà vu jest jak najbardziej uzasadnione $)^{51}$.

Aby ustalić, czy normę tę można odnieść do zmiany władzy w Mjanmie w następstwie przewrotu z 1 lutego 2021 roku, należy zacząć od ustalenia, jak dokładnie powinniśmy ją definiować. Demokracja nie ma jednej ugruntowanej definicji ${ }^{52}$, jednak warto za E. de Wet uznać, że pewne minimum, bez którego nie będzie ona istnieć, wyznacza instytucja wolnych i równych wyborów (proceduralna definicja demokracji ${ }^{53}$. Jak wskazuje Weller, da się zidentyfikować dwa elementy „normy demokratycznej”, z którymi łączą się, w jego opinii, twarde normatywne zobowiązania: zakaz przewrotów niezgodnych z konstytucją oraz odmowy uznania wyników wyborów przez rząd - w razie naruszenia tych zobowiązań legalność powinna przeważyć nad efektywnością ${ }^{54}$. W Mjanmie te dwa postulowane przez Wellera zobowiązania zostały niewątpliwie naruszone: jak już wskazano, wprowadzenie stanu wyjątkowego nie zostało dokonane zgodnie z konstytucją, podobnie jawne pogwałcenie tej normy stanowi odrzucenie wyniku wyborów przewrót wojskowy hipotetycznie można więc odnieść do tak ujmowanej normy demokratycznej i ocenić jako jej naruszenie. Gdyby opowiedzieć się za szerszym rozumieniem demokracji (materialna definicja demokracji), zarzut ten dałoby się wzmocnić, przywołując także rażące naruszenia w obszarze praw człowieka: tła przewrotu dopełnia bowiem wiele działań junty wymierzonych przeciwko przeciwnikom politycznym (wspomniane arbitralne aresztowania) lub nakierowanych na ograniczenie swobód obywatelskich: Rada Administracyjna przyjęła szereg dekretów mających na celu zwłaszcza zwalczanie swobody wypowiedzi, które raport Andrewsa określa wprost jako „drakońskie” ${ }^{55}$.

51 Ibidem; zob. UN General Assembly, Situation in Myanmar, 18.12.1992 A/RES/47/144, https://undocs.org/pdf?symbol=en/A/RES/47/144 (dostęp: 14.04.2021).

52 Podstawowa rozbieżność $\mathrm{w}$ definicjach demokracji wiąże się $\mathrm{z}$ alternatywą między definicjami proceduralnymi i materialnymi. Podczas gdy ta pierwsza grupa definicji skupia się na procesie wyborczym i gwarancjach udziału w wyborze rządu, w ujęciu materialnym demokracja rozumiana jest szerzej jako powiązana z ochroną praw człowieka - ten brak jasności tworzy znaczną przeszkodę w rzeczywistym wykształceniu się wiążącej normy demokratycznej (zob. G.H. Fox, Democracy, Right to, International Protection, Max Planck Encyclopedia of Public International Law, https://opil.ouplaw.com/view/10.1093/law:epil/9780199231690/law-9780199231690-e773?rs key=TCH3Jm\&result=1\&prd=OPIL (dostęp: 26.04.2021), pkt 8-13.

53 E. de Wet, From Free Town to Cairo via Kiev: the Unpredictable Road of Democratic Legitimacy in Governmental Recognition, „AJIL Unbound” 2014, nr 108, s. 203.

${ }^{54}$ M. Weller, op. cit.

55 Można w tym kontekście odnotować wprowadzenie do kodeksu karnego przepisów penalizujących mowę, która może „wzbudzać społeczny lęk lub niepokój” albo prowadzi innych do zakłócenia „spokoju publicznego", albo nowelizację ustawy o transakcjach elektronicznych z 2004 roku, która przyznaje juncie bardzo daleko idącą swobodę w zwalczaniu dezinformacji w internecie i wyposaża $\mathrm{w}$ instrumenty inwigilacji, nie poddając ich proceduralnym ograniczeniom. Zob. T.H. Andrews, op. cit., s. 10. 
Pytanie o to, czy w istocie doszło do wykształcenia się normy demokratycznej, a także o ewentualny zakres jej obowiązywania, nabiera więc w tym wypadku szczególnej wagi - warunkowałaby ona bowiem po stronie członków społeczności międzynarodowej obowiązek odmowy uznania junty za rząd Mjanmy. Poszukując takiej normy, należałoby na początku wskazać, że pojęcie prawa do demokratycznych rządów nie pojawia się systematycznie w istotnych międzynarodowych konwencjach dotyczących praw człowieka: warto odnotować za G.H. Foxem, że przykładowo Europejska konwencja praw człowieka tylko w preambule zdawkowo wspomina, że zachowanie podstawowych wolności „opiera się [...] na rzeczywiście demokratycznym ustroju politycznym" "56, a w przyjętej przez Komisję Praw Człowieka ONZ serii rezolucji podkreślających znaczenie demokracji w latach 1999-2005 zaledwie jedna z nich (pierwsza) ${ }^{57}$ odnosi się do prawa do demokracji ${ }^{58}$. Wyjątkiem tu jest Organizacja Państw Amerykańskich (OPA), która jako jedyna taka organizacja w przyjętej w 2001 roku Międzyamerykańskiej Karcie Demokratycznej wprost proklamuje prawo do demokracji ${ }^{59}$. Wobec niemożności zidentyfikowania normy konwencyjnej, którą można by zastosować do sytuacji w Mjanmie, należy zbadać, czy istnieje w prawie międzynarodowym zbliżona norma demokratyczna o charakterze zwyczajowym ${ }^{60}$.

Zwyczaj międzynarodowy jako źródło prawa międzynarodowego definiowany jest jako praktyka uznana za prawo ${ }^{61}$; tym samym wymaga on jednoczesnego zaistnienia elementu obiektywnego (usus — praktyka) i subiektywnego (opinio

56 Europejska konwencja o ochronie praw człowieka i podstawowych wolności, 4.11.1950, https:/opil.ouplaw.com/view/10.1093/law:epil/9780199231690/law-9780199231690-e773?rskey$=$ POzQSd\&result=2\&prd=OPIL (dostęp: 23.04.2021).

57 Zob. United Nations Human Rights Commission, Resolution on Promotion of Democracy, 28.04.1999, HR/CN/937, https://www.un.org/press/en/1999/19990428.HRCN937.html (dostęp: 25.04.2021).

58 G.H. Fox, op. cit., pkt 4.

59 Organization of American States, Inter-American Democratic Charter, 2001, https://www. oas.org/charter/docs/resolution1_en_p4.htm (dostęp: 24.04.2021).

60 Można też stawiać pytania o status normy demokratycznej jako zasady ogólnej: uwzględniając status prawa do samostanowienia, wyrażonego w rezolucji ZO ONZ nr 2625, jako jednej z zasad prawa międzynarodowego (zob. UN General Assembly, Declaration on Principles of International Law), niewątpliwie interesującym kierunkiem badań będzie poszukiwanie jego relacji z normą demokratyczną - czy inferencyjnie da się ją z niego wywieść; na tym etapie rozwoju prawa międzynarodowego to powiązanie nie będzie jednak wystarczająco mocne: zważywszy na to, że prawo do samostanowienia obejmuje prawo ludności danego państwa do swobodnego wyboru ustroju politycznego, nie należy przesądzać, że ustrój taki powinien być koniecznie ustrojem demokratycznym, tym bardziej że tę swobodę wyboru zabezpieczają inne zasady potwierdzone w rezolucji, jak zakaz ingerencji oraz suwerenna równość państw; zob. D. Thürer, T. Burri, Self-Determination, Max Planck Encyclopedia of Public International Law, https:/opil.ouplaw.com/view/10.1093/ law:epil/9780199231690/law-9780199231690-e873?prd=OPIL\#law-9780199231690-e873-div2-3, pkt 17 (dostęp: 24.04.2021).

61 Statut Międzynarodowego Trybunału Sprawiedliwości, Dz.U. 1947 Nr 23, poz. 90, art. 38 ust. 1 lit. c. 
iuris sive necessitatis - przeświadczenie o mocy wiążącej), wobec których w doktrynie i orzecznictwie formułowane są dalsze szczegółowe wymagania ${ }^{62}$. Praktyka, jak wskazuje się w orzecznictwie MTS, powinna być „stała i jednolita"63 lub „rozpowszechniona i co do zasady jednolita"64. Brak konsekwencji w praktyce państw trafnie punktuje de Wet, analizując przypadki zaistniałe na kontynencie afrykańskim, w tym uznanie Narodowej Rady Tymczasowej w Libii za legalny rząd, choć nie została ona powołana w demokratycznych wyborach, a także rewolucji w Egipcie, gdzie Unia Afrykańska potępiła obalenie prezydenta M. Morsiego po roku od wyborów jako niekonstytucyjną zmianę rządu, podczas gdy państwa Zachodu, w tym Stany Zjednoczone i UE, nie były skłonne do stwierdzenia, że doszło do nielegalnego przewrotu, i nie domagały się przywrócenia Morsiego na urząd ${ }^{65}$. Tylko w pewnych szczególnych przypadkach, jak dowodzi Roth, państwom udało się osiągnąć porozumienie ponad podziałami kulturowymi i ideologicznymi w reakcji na określone wewnętrzne konflikty i podjąć wspólne działanie, jednak przytaczane wówczas motywy nie pozwalają na rekonstrukcję spójnego opinio iuris ${ }^{66}$. Trudność w zakresie wykazania elementu subiektywnego wiąże się ze wspomnianymi rozbieżnościami w rozumieniu demokracji: wobec niejasności co do tego, jak definiować demokratyczne rządy, nie można oczekiwać, że dojdzie do wygenerowania opinio iuris ${ }^{67}$. Co więcej, status tak rozumianej normy będzie zróżnicowany w zależności od danego regionu — podczas gdy OPA, jak wspomniano, proklamuje prawo do demokracji, a w Europie znaczenie demokracji jest szeroko eksponowane i wsparte zespołem gwarancji czy to na forum Rady Europy, UE, czy OECD, to już w systemie azjatyckim, jak pisze Fox, trudno będzie mówić o istnieniu norm demokratycznych jako takich ${ }^{68}$. Gdyby więc badać sprawę pod kątem powstania zwyczaju partykularnego w poszczególnych regionach (mając na względzie, że do stwierdzenia obowiązywania zwyczaju regionalnego „konieczny jest mocniejszy i bardziej przekonywający dowód”

62 R. Wolfrum, Sources of International Law, Max Planck Encyclopedia of Public International Law, https://opil.ouplaw.com/view/10.1093/law:epil/9780199231690/law-9780199231690-e1471? rskey=wxo7pt\&result=1\&prd=OPIL, pkt 24 (dostęp: 16.04.2021).

63 International Court of Justice (ICJ), Asylum Case (Colombia v. Peru). Judgment, 20.11.1950, s. 276.

${ }^{64}$ International Court of Justice (ICJ), North Sea Continental Shelf Cases (Federal Republic of Germany v. Denmark; Federal Republic of Germany v. Netherlands). Judgment, I.C.J. Reports 1969, s. 43.

65 E. de Wet, op. cit., s. 204-205.

66 Ibidem, s. 411-412.

67 G.H. Fox, op. cit., pkt 6.

68 Ibidem, pkt 36. Bardzo ciekawie na ten temat pisze S. Varayudey, który zwraca uwagę na odmienną hierarchię wartości w azjatyckim kręgu kulturowym, gdzie na pierwszy plan wysuwa się konfucjanizm, szacunek dla starszych, społeczna harmonia i dyscyplina, interesy zbiorowości, a nie polityczna wolność taka, jak rozumie ją Zachód (zob. S. Varayudey, A Right to Democracy in International Law: Its implications for Asia, „Annual Survey of International \& Comparative Law” 12, 2006, nr 1, art. 2, s. 13). 
w odniesieniu do elementu obiektywnego i subiektywnego ${ }^{69}$ ) należy spodziewać się, że w wypadku państw Azji stwierdzenie obowiązywania takiej normy nie będzie możliwe.

Wydaje się więc, że narracja o ukształtowaniu się normy demokratycznej jest nadmiernie idealistyczna, przesiąknięta duchem „końca historii"70, albowiem jak zauważa B. Roth: „społeczność międzynarodowa wciąż często nie jest w stanie osiągnąć konsensusu wymaganego do zajęcia stanowiska przeciwko rządom de facto i stronom wojującym, które działają przeciw werdyktom wydanym w »wolnych i uczciwych « procesach wyborczych" "71. Tak jak przekonuje Roth, demokratyczny legitymizm pozostaje w sferze aspiracji, a brak demokratycznego mandatu nie powinien warunkować odmowy uznania (,stabilne dyktatury zazwyczaj były wolne od krytyki swoich systemów rządów jako takich") ${ }^{72}$. Zgodzić się więc należy z de Wet, która stwierdza wprost, że ,,praktyka państw nie potwierdza konkluzji, by zwyczajowe prawo międzynarodowe zobowiązywało państwo do wstrzymania uznania rządu, który przejął władzę metodą niekonstytucyjną" "73.

\section{Podsumowanie}

Bez wątpienia sytuacja w Mjanmie, ze względu na niekonstytucyjny tryb zmiany władz, wpisuje się $\mathrm{w}$ te, w których prawo międzynarodowe przewiduje zastosowanie instytucji uznania rządu. Należy jednak stwierdzić, że dziś kryterium efektywności wysuwa się na pierwszy plan i wskazuje państwom trzecim konkretną ścieżkę postępowania; na gruncie norm prawa międzynarodowego dotyczących uznania rządu junta w Mjanmie powinna być traktowana jako podmiot uprawniony do występowania w imieniu państwa. Norma demokratyczna stanowi cenny punkt odniesienia w debacie na temat sytuacji w Mjanmie, jednak obecnie, zważywszy na aktualny etap rozwoju prawa międzynarodowego, nie sposób wywieść z niej konkretnych normatywnych skutków, należy jasno stwierdzić, że jak dotąd nie powstał nowy wzorzec przesłanek zgodnego z prawem międzynarodowym uznania rządu.

Nie oznacza to jednak, że prawo międzynarodowe pozostaje wobec kryzysu w tym państwie zupełnie irrelewantne. Nie bez znaczenia pozostają kompetencje RB ONZ, która na gruncie art. 39 może stwierdzić stan zagrożenia lub naruszenia pokoju, co umożliwiłoby zastosowanie konkretnych środków, aczkolwiek wobec wskazywanych tu różnic w stanowiskach stałych członków scenariusz przyjęcia przez Radę bardziej aktywnej postawy wydaje się mało prawdopodobny. Ludność

69 W. Czapliński, A. Wyrozumska, op. cit., s. 121.

70 Zob. F. Fukuyama, The End of History?, „The National Interest” 1989, nr 16, s. 3-18.

71 B. Roth, Governmental Illegitimacy in International Law, Oxford 2010, s. 411.

72 Ibidem, s. 411-412.

73 E. De Wet, op. cit., s. 206. 
Mjanmy wciąż zarazem korzysta z ochrony na gruncie międzynarodowych praw człowieka $^{74}$ lub, jeżeli $\mathrm{w}$ następstwie potencjalnej eskalacji możliwe będzie zakwalifikowanie sytuacji jako konfliktu zbrojnego, także międzynarodowego prawa humanitarnego. Kwestią w szczególności wymagającą rozważenia w kontekście wydarzeń w Mjanmie jest obowiązek nieuznawania sytuacji nielegalnych, którego istnienie jest dyskutowane już od znacznego czasu w doktrynie ${ }^{75}$. P. Saganek twierdzi, że obowiązek taki może dotyczyć tylko sytuacji sprzecznych z prawem międzynarodowym, dlatego nie będzie adekwatny do uznania rządu, które pojawia się przy zmianie sprzecznej z prawem krajowym ${ }^{76}$. Niemniej nie należy wykluczać, że przewrót wojskowy był nie tylko pogwałceniem norm konstytucyjnych, ale również norm prawa międzynarodowego: warto tu zasygnalizować, że zasadne wydaje się zbadanie sytuacji z perspektywy prawa do samostanowienia ludności Mjanmy, którego naruszenie warunkowałoby zakaz uznania sytuacji nielegalnej po stronie państw trzecich ${ }^{77}$. Jest to już jednak zagadnienie wymagające odrębnej analizy.

\section{Bibliografia}

Czapliński W., Wyrozumska A., Prawo międzynarodowe publiczne. Zagadnienia systemowe, Warszawa 2014.

Dynia E., Uznanie rzadu w prawie międzynarodowym, Lublin 1997.

Fox G.H., Democracy, Right to, International Protection, Max Planck Encyclopedia of Public International Law, https://opil.ouplaw.com/view/10.1093/law:epil/9780199231690/law-97801992 31690-e773?rskey=TCH3Jm\&result=1\&prd=OPIL.

Franck T.M., The Emerging Right to Democratic Governance, „The American Journal of International Law" 86, 1992, nr 1.

Frowein J.A., Recognition, Max Planck Encyclopedia of Public International Law, https://opil.ou plaw.com/view/10.1093/law:epil/9780199231690/law-9780199231690-e1086?rskey=wHvNc2\&result $=1 \&$ prd $=$ OPIL.

Fukuyama F., The End of History?, „The National Interest” 1989, nr 16.

Janik R., European Recognition Practice on Venezuela: The Devil in the Details, „OpinioJuris” 8.02.2019, http://opiniojuris.org/2019/02/08/european-recognition-practice-on-venezuela-thedevil-in-the-details/.

Jessup P.C., The Estrada Doctrine, „The American Journal of International Law” 25, 1931, nr 4.

74 Mjanma przystąpiła do Międzynarodowego Paktu Praw Gospodarczych, Społecznych i Kulturowych oraz Konwencji o zwalczaniu wszelkich form dyskryminacji kobiet w 1997 roku; od 1991 roku jest też stroną Konwencji o prawach dziecka (OHCHR, Status of ratification. Interactive dashboard, https://indicators.ohchr.org (dostęp: 16.04.2021)).

75 P. Saganek, Uznanie jako akt jednostronny państwa a systemowy charakter prawa międzynarodowego, [w:] Państwo a prawo międzynarodowe jako system prawa, red. R. Kwiecień, Lublin 2015, s. 139.

76 Ibidem, s. 140.

77 Zob. International Court of Justice (ICJ), Legal Consequences of the Construction of a Wall in the Occupied Palestinian Territory, Advisory Opinion, I.C.J. Reports 2004, s. 136, pkt 159. 
Johnson L.D., What's wrong with this picture? The UN Human Rights Council hears the military Junta as the legitimate government of Myanmar, EJIL: Talk!, 31.03.2021, https://www.ejiltalk. org/whats-wrong-with-this-picture-the-un-human-rights-council-hears-the-military-junta-asthe-legitimate-government-of-myanmar/.

Lauterpacht H., Recognition of Governments: I, „Columbia Law Review” 45, 1945, nr 6.

Marks S., What has Become of the Emerging Right to Democratic Governance?, „The European Journal of International Law" 22, 2011, nr 2.

Roth B., Governmental Illegitimacy in International Law, Oxford 2010.

Saganek P., Uznanie jako akt jednostronny państwa a systemowy charakter prawa międzynarodowego, [w:] Państwo a prawo międzynarodowe jako system prawa, red. R. Kwiecień, Lublin 2015.

Selth A., Interpreting Myanmar: A Decade of Analysis, Canberra 2020.

Stansifer C.L., Application of the Tobar Doctrine to Central America, „The Americas” 23, 1967, nr 3.

Stokke K., Myint Aung S., Transition to Democracy or Hybrid Regime? The Dynamics and Outcomes of Democratization in Myanmar, „The European Journal of Development Research” 32, 2019, $\mathrm{nr} 1$.

Talmon S., Recognition of Governments: An Analysis of the New British Policy and Practice, „British Yearbook of International Law" 63, 1992, nr 1.

Talmon S., Recognition of Governments in International Law: With Particular Reference to Governments in Exile, Oxford 2001.

Talmon S., Recognition of the Libyan National Transitional Council, „ASIL Insights” 15, 2011, nr 16, https://www.asil.org/insights/volume/15/issue/16/recognition-libyan-national-transitionalcouncil.

Thürer D., Burri T., Self-Determination, Max Planck Encyclopedia of Public International Law, https://opil.ouplaw.com/view/10.1093/law:epil/9780199231690/law-9780199231690-e873? prd=OPIL\#law-9780199231690-e873-div2-3.

Varayudey S., A Right to Democracy in International Law: Its implications for Asia, „Annual Survey of International \& Comparative Law" 12, 2006, nr 1, art. 2.

Weller M., Myanmar: Testing the Democratic Norm in International Law, EJIL: Talk!, 30.03.2021, https://www.ejiltalk.org/myanmar-testing-the-democratic-norm-in-international-law/.

Wet E. de, From Free Town to Cairo via Kiev: the Unpredictable Road of Democratic Legitimacy in Governmental Recognition, „AJIL Unbound” 2014, nr 108.

Wolfrum R., Sources of International Law, Max Planck Encyclopedia of Public International Law, https://opil.ouplaw.com/view/10.1093/law:epil/9780199231690/law-9780199231690-e1471? rskey=wxo7pt\&result $=1 \&$ prd $=$ OPIL.

\section{Akty prawne}

Karta Narodów Zjednoczonych, Dz.U. 1947 Nr 23, poz. 90.

Statut Międzynarodowego Trybunału Sprawiedliwości, Dz.U. 1947 Nr 23, poz. 90.

Europejska konwencja o ochronie praw człowieka i podstawowych wolności, 4.11.1950, https:// opil.ouplaw.com/view/10.1093/law:epil/9780199231690/law-9780199231690-e773?rskey $=$ POzQSd\&result=2\&prd=OPIL.

UN General Assembly, Declaration on Principles of International Law concerning Friendly Relations and Cooperation among States in accordance with the Charter of the United Nations, 24.10.1970, A/RES/2625(XXV), https://digitallibrary.un.org/record/202170.

UN General Assembly, The situation of democracy and human rights in Haiti, 11.10.1991, A/RES/ 46/7, https://documents-dds-ny.un.org/doc/RESOLUTION/GEN/NR0/580/95/IMG/NR0580 95.pdf?OpenElement. 
UN General Assembly, Situation in Myanmar, 18.12.1992 A/RES/47/144, https://undocs.org/pdf? symbol=en/A/RES/47/144.

United Nations Human Rights Commission, Resolution on Promotion of Democracy, 28.04.1999, HR/CN/937, https://www.un.org/press/en/1999/19990428.HRCN937.html.

Organization of American States, Inter-American Democratic Charter, 2001, https://www.oas.org/ charter/docs/resolution1_en_p4.htm.

\section{Orzecznictwo}

Aguila-Amory and Royal Bank of Canada claims (Great Britain v. Costa Rica), 18.10.1923, Reports of International Arbitral Awards, t. 1.

International Court of Justice (ICJ), Asylum Case (Colombia v. Peru). Judgment, 20.11.1950.

International Court of Justice (ICJ), North Sea Continental Shelf Cases (Federal Republic of Germany v. Denmark; Federal Republic of Germany v. Netherlands). Judgment, I.C.J. Reports 1969.

International Court of Justice (ICJ), Legal Consequences of the Construction of a Wall in the Occupied Palestinian Territory, Advisory Opinion, I.C.J. Reports 2004.

\section{Artykuły prasowe}

Barker A., Myanmar election: Why can't Aung San Suu Kyi be president and why is the country in leadership limbo?, „ABC News” 10.11.2015, https://www.abc.net.au/news/2015-11-10/myanmarelection-explained/6928542?nw $=0$.

BBC News, Myanmar coup: Aung San Suu Kyi detained as military seizes control, https://www.bbc. com/news/world-asia-55882489, 1.02.2021.

Brooks S.M., Stothard D., China's Myanmar Mess, „The Diplomat” 16.03.2021, https://thediplomat.com/2021/03/chinas-myanmar-mess/.

Gladstone R., Illegal Walkie-Talkies and Other 'Crimes' in Authoritarian Societies, „The New York Times" 8.02.2021, https://www.nytimes.com/2021/02/08/world/asia/authoritarians.htm1? searchResultPosition=87.

Lubina M., Birma: zdyscyplinowana demokracja, „Miesięcznik Znak” 10.2015, https://www.miesie cznik.znak.com.pl/birma-zdyscyplinowana-demokracja/.

Lubina M., Krwawy księżyc, „Polityka” 2021, nr 16 (3308).

McDonald T., Myanmar coup: Could sanctions on the military ever work?, „BBC News” 9.04.2021, https://www.bbc.com/news/business-56248559.

Mendelson A., Vying for legitimacy as Myanmar's recognised government, who are the CRPH?, "Globe" 12.03.2021, https://southeastasiaglobe.com/crph-myanmar/.

Myers L., Myanmar Is on the Precipice of Civil War, „Foreign Policy” 8.04.2021, https://foreignpolicy.com/2021/04/08/myanmar-military-coup-ethnic-armed-organizations-civil-war/.

\section{Raporty}

Andrews T.H., Report of the Special Rapporteur on the situation of human rights in Myanmar, A/HRC/46/56, 4.03.2021.

Human Rights Watch, Myanmar: Election Fundamentally Flawed, 5.10.2020, https://www.hrw.org/ news/2020/10/05/myanmar-election-fundamentally-flawed.

Rodriguez-Cedeno V., Sixth report on unilateral acts of States, A/CN.4/519, 2003.

Studia nad Autorytaryzmem i Totalitaryzmem 43, nr 3, 2021

(C) for this edition by CNS 


\section{Inne}

Council of the EU, Myanmar/Burma: EU sanctions 11 people over the recent military coup and ensuing repression, 22.03.2021, https://www.consilium.europa.eu/en/press/press-releases/2021/ 03/22/myanmar-burma-eu-sanctions-11-people-over-the-recent-military-coup-and-ensuingrepression/.

OHCHR, Status of ratification. Interactive dashboard, https://indicators.ohchr.org.

UN Geneva, After a Decade of Civilians Bearing the Brunt of the Conflict in Syria, it is Time to Put Them First and Support an Immediate Nation-wide Ceasefire, Commission of Inquiry on Syria Tells Human Rights Council, 11.03.2021, https://www.ungeneva.org/en/news-media/meetingsummary/2021/03/afternoon-after-decade-civilians-bearing-brunt-conflict-syria-it.

UN Human Rights South-East Asia Regional Office, UN Human Rights Office urges suspension of returns to Myanmar, 1.04.2021, https://bangkok.ohchr.org/myanmar-returns/.

United Nations Human Rights Council, Human Rights Council calls for release of all arbitrarily detained persons in Myanmar, and lifting of state of emergency, 12.02.2021, https://www.ohchr. org/EN/HRBodies/HRC/Pages/NewsDetail.aspx?NewsID=26748\&LangID=E. 